\title{
Gazetecilerin Kriz Dönemlerinde Halkla iliş̧kiler Çalışanlarına Bakış Açılarının Belirlenmesine Yönelik Bir Araştırma ${ }^{1}$ Özlem DUĞAN
}

Dr. Öğr. Üyesi Uşak Üniversitesi İletişim Fakültesi Halkla Illişkiler ve Reklamcılık Bölümü ozlem.dugan@usak.edu.tr Orcid: 0000000190287989

\author{
Semra AKINCI \\ Arş. Gör. \\ Anadolu Üniversitesi İletişim Bilimleri Fakültesi \\ Halkla Illişkiler ve Reklamclık Bölümü \\ semra_akinci@anadolu.edu.tr \\ Orcid: 0000000299956760
}

\begin{abstract}
Research on Determination of Point Views of Journalists About Public Relations Practitioners in Crisis Periods

In crisis periods, reporters try to announce their news to the public by gathering them quickly. Especially in crisis situations, people who are involved with the public need to bring right information to the right public at the right time. This study was conducted in order to determine the outlook of media workers to public relations practitioners in crisis times. In-depth interviews were conducted with 21 journalists for this study. As a result of the study, it has been found that public relations practitioners are not able to provide enough information at the right time, they are not as helpful as journalists, they are the news sources but this can change depending on the institution, it is widely believed that public relations practitioners experience difficulties in confirming information and information pollution in crisis periods. It was found that $57 \%(n=12)$ of journalists have not received aneducation on crisis management. Journalists suggest that institutions should act calmly during crises, analyze crisis properly, and convey accurate information through media. Journalists, who share an opinion as the first information in crisis, should be shared with opinion leaders, media and institution 1 Bu makale "16. Uluslararası Milenyumda iletişim Sempozyumu-CIM-2018'de sunulmuş ve özet bildiri olarak bildiri kitapçığında yayınlanmıştır
\end{abstract}

DOI: $10.16878 /$ gsuilet.459093 
employees. It is stated that if a crisis is directed by a leader, it can be overcome with least harm and the crisis can turn into an opportunity for institution thanks to right guidance.

Keywords: Crisis Management, Journalists, Public Relations Practitioners.

\section{Résumé}

Une recherche sur la détermination des perspectives des journalistes sur les employés des relations publiques saucours de la crise

En temps de crise, les journalistes tentent d'agir rapidement et transmettent les informations au public. Dans un environnement concurréntiel difficile, les spécialistes des relations publiques devraient faciliter le travail des journalistes en fournissant les bonnes informations au bon moment et aux bonnes personnes en cas de crise. Le but de cette étude est de déterminer ce qu'ils pensent les employés des médias des relations publiques en situation de crise. Pour cette étude les entretiens détaillés ont été réalisés avec 21 journalistes. Selon les résultats de l'étude, d'apres les employés des médias, les employés des relations publiques tardent à fournir des informations adéquates aux journalistes, ils ne peuvent pas aider suffisamment les journalistes, ces employés sont des sources d'information. Mais ce point de vue change selon l'institution, les relations publiques tentent de cacher des information aux journalistes en temps de crise, ils estiment que ce sont eux qui ont le plus de mal à vérifier les informations. II a été révélé que $57 \%(n=12)$ des journalistes ne sont pas scolarisés. Au cours de la période de crise, les journalistes suggèrent que les institutions agissent avec calme, analysent la crise et que les informations appropriées soient transmise aux médias par le biais des médias.

Mots clés: gestion de crise, journalistes, employés des relations publiques

\section{Öz}

Kriz dönemlerinde gazeteciler hızlı hareket ederek haberlerini topluma duyurma çabasındadırlar. Ozellikle kriz durumlarında halkla ilişkiler çalışanlarının doğru bilgivi, doğru zamanda ve doğru kişilere ulaştırmaları gerekir. Bu çalışma medya çalışanlarının krizlerde halkla ilişkiler çalışanlarına bakış açııını belirlemek amacıyla yapılmıştır. Çalışma için 21 gazeteci ile derinlemesine görüşme yapılmıştır. Çalışma sonucunda halkla ilişkiler çalışanlarının gazetecilere, yeterli bilgiyi doğru zamanda ulaştırmakta geç kaldıkları, gazetecilere yeteri kadar yardımcı olamadıkları, haber kaynağı oldukları ancak bu durumun kuruma göre değiştiği, halkla ilişkilerin kriz dönemlerinde gazetecilerden bilgiyi saklamaya çalıștıkları, kriz dönemlerinde en çok bilgi kirliliği ve bilgileri doğrulatamama konusunda zorluk yaşadıkları görüşü hâkimdir. Kriz ile ilgili gazetecilerin \% 57 (n=12)'sinin eğitim almadıkları ortaya çıkmışıtır. Gazeteciler, kriz döneminde kurumların soğukkanlı hareket etmelerini, krizi doğru analiz etmelerini, doğru bilgilerin gerekli yerlere medya aracılığıyla ulaştırılmasını önermektedir. Krizde ilk bilgilerin kanaat önderleri, medya ve kurum çalışanları ile paylaşılması gerektiği düşüncesini paylaşan gazeteciler, krizi liderin yönetmesi durumunda krizin en az zararla atlatılabileceği ve doğru yönlendirme ile kurum için fırsata dönüşebileceğini belirtmişlerdir.

Anahtar kelimeler: Kriz Yönetimi, Gazeteciler, Halkla Ilişkiler Çalışanları 


\section{Giriş}

Medya ile halkla ilişkiler arasında kopmaz bir bağ vardır. Bu bağ her iki tarafın işini yapabilmesi için gerekmektedir. Medya çalıșanı haber yapabilmek için halkla ilişkiler çalışanından kurumda meydana gelen olaylarla ilgili bilgi talep ederken, halkla ilişkiler çalışanı da medya aracılığıyla çalıştığı kurumun tanıtımını yapma çabası içerisindedir. Halkla ilişkiler çalışanlarının gazetecilerle sağlıklı ilişki geliştirmeleri bir öncelik olmalıdır. Gazetecilerle ilişkilerin doğru yönetilmesi halkla ilişkiler profesyonelleri için önemli bir stratejik amaçtır (Callison ve Seltzer, 2010). Macnamara (2014, s. 739), son 100 yıl içerisinde yapılan araștırmalara göre, medyanın içeriğinin \% 40 ile \% 75'i halkla ilişkiler kaynaklı ya da halkla ilişkiler çalışmaları tarafından etkilenmiş haberlerden oluştuğunu belirtmektedir. Gazeteciler için önemli haber kaynağı olarak değerlendirilen halkla ilişkiler çalışanlarının doğru bilgiyi doğru zamanda gazetecilere iletmesi gerekmektedir. Gazetecinin doğru bilgiyi kısa sürede elde ederek haberini zamanında kamuoyuna ulaştırması başarı olarak değerlendirilmektedir. Özellikle kriz dönemlerinde, kamuoyunu ilgilendiren önemli olaylarda kamuoyunun merakını ve endişesini gidermek için çalışan gazetelerin bilgiye kısa sürede ulaşması elzemdir. Halkla ilişkiler çalışanı ise doğru bilgiyi kısa sürede ulaştırarak gazetecinin işini kolaylaştırmaktadır. Bu bağlamda değerlendirildiğinde gazeteciler ile halkla ilişkiler çalışanları arasındaki iletișimin güvenilir bir iletișim temeline dayandırılması ilişkinin sürekliliği için de gerekmektedir. Gazeteciler ile halkla ilişkiler çalışanları arasındaki ilişkiyi kriz dönemleri açısından inceleyen bu çalışma medya çalışanlarının kriz dönemlerinde halkla ilişkiler çalışanlarından beklentilerini ortaya koymaya yöneliktir. Çalıșma kapsamında ilk olarak halkla ilişkiler ve medya ilişkisi, kriz dönemlerinde habercilik ve halkla ilişkiler çalışmaları ile literatür oluşturulmuş, son olarak 21 gazeteci ile derinlemesine görüşme gerçekleştirilmiştir.

\section{Halkla İlişkiler ve Medya İlişkisi}

Gazetecinin mesleği gereği haberini yapmaya çalıșırken halkla ilișkiler biriminin vereceği bilgilere intiyacı vardır. Aynı şekilde halkla ilişkiler çalışanı da kurumunu tanıtmak için gazetecilere gereksinim duyar. Enformasyonu toplayan ve doğrulayan, bilgiyi hitap ettiği topluma göre işleyen ve anlaşılır kılan gazeteci, bu görevi yerine getirirken, haber için gerekli bilgileri öğrenmeye çalışmaktadır (Erdoğan, 2006, s. 55-56). Gazeteci, bir olay ya da konu hakkında enformasyonu kendi çabasıyla elde edebileceği gibi çoğu zaman da haber kaynaklarından elde etmektedir (Aslan, 2008, s. 142; Tılıç, 1998, s. 55). Halkla ilişkiler çalışanları, haber üretim sürecinde gazetecilerin ișlerini kolaylaştırmaktadır (Cameron vd., 1997). Kadıbeşegil (2001, s. 54), halkla iliş̧kiler çalışanlarının zamanında, güvenilir, belgelenmiş kaynaklardan bilgileri sunabildikleri sürece gazeteciler için iyi bir haber kaynağı olabileceklerini vurgulamaktadır. Halkla ilişkiler medya ilişkisini tanımlayan Johnston $(2013$, s. 6) medya ilişkilerini, “kişi, grup ya da kurum ve medya arasındaki iletişimin ve ilişkilerin sürekli kolaylaştıııması ve koordinasyonu" olarak ifade etmektedir. Halkla ilișkiler açısından en önemli paydaş gruplarından biri olarak ifade edilen (Ihlen ve Pallas, 2014; Yayınoğlu Eraslan, 2013, s.
29) medya, kurumlar için özel önem arz etmektedir. Gazeteciler halkla ilișkileri daha fazla bilgi kaynağı olarak görmekte ve bilgi talep etmektedir (White ve Hobsbawm, 2007, s. 291). Sabuncuoğlu (2004, s. 129), bir işletmenin halkla ilişkiler çalışmalarının en yoğunlaștığı alanın medya ile kurulan ilişkiler olduğuna dikkat çekmektedir. Oktay'a göre (1996, s. 99), medya ilişkileri belirli bir kuruluş ile medya arasındaki karşılıklı çıkarlara dayanan amaçların uzlaştıııması temeline dayanmaktadır. Halkla ilişkilerin çalıșma alanına hangi konuların haber olabileceğinin gözlemini yapmak, bilgiyi elde etmek ve görsel malzemeleri ile birlikte gazeteciye değerlendirmesi için sunmak girmektedir (Kadıbeşegil, 2001, s.55). Ancak birbirine gereksinim duyan halkla ilişkiler çalışanı ile gazeteci arasındaki işbirliği, bazen çatışmalar nedeniyle sağlıklı bir zeminde ilerlememektedir (Öksüz ve Korap Özel, 2015, s. 23). Halkla ilișkiler çalıșanları ile gazeteciler arasında yaşanan bu kopmaz bağ bazen gerginliklere neden olabilmektedir. Halkla ilişkiler çalışanları ve gazeteciler arasındaki ilişki (White ve Hobsbawm, 2007 s. 284) her iki tarafın diğerine karșı olan önyargılı yaklașımları nedeniyle bozulabilmektedir. Cameron ve arkadaşlarına göre (1997, s. 120), gazeteciler, halkla ilişkiler çalışanlarının profesyonel olmadıklarını ve ihtiyaç duydukları açık, öz ve doğru bilginin aktarılmadığını düșünmektedir. Pincus ve arkadașları (1993) tarafından yapılan araștırmada gazeteciler, halkla ilişkiler çalışanlarına ve halkla ilişkilerden gelen materyallere karşı olumsuz algılara sahiptir. Amerika'da 225 gazeteci ile yapılan bir araştırmada gazetecilerin \% 47'sinin halkla ilișkiler uzmanlarını bir dert olarak gördükleri, \% 46'sının halkla iliškiler uzmanlarının doğruyu söylemediklerine inandıklarını ortaya koymaktadır (Patricia, 1999). White ve Hobsbawm (2007, s. 284) gazetecilerin, halkla ilişkiler çalışanlarını kuşkulu bir kaynak olarak gördügünü ifade etmektedir. Cameron ve arkadaşları (1997, s. 118) tarafından yapılan araștırmada gazetecilerin halkla ilișkiler uzmanlarını haber kaynağı olarak güvenilmez bulduklarını ortaya koymaktadır. Her iki taraf açısından zor bir ilişki süreci olarak görülse de halkla ilişkiler çalışanları ile gazetecile arasındaki ilișki devam etmektedir. Halkla ilișkiler çalıșmalarında medya ile kurulacak iyi ilişkiler öncelikli yer tutmaktadır (Çamdereli, 2000, s. 89). Bir halkla ilişkiler çalışanı dürüst, tam ve doğru bilgiler verdiği sürece medyanın güvenini, saygınlığını kazanarak kitle iletişim aracından yararlanabilmektedir (Sabuncuoğlu, 2004, s.130). Dürüst ve istikrarlı bir ilișki sürdürebilmek için ilk olarak halkla ilișkiler çalıșanının, medya tarafından güvenilir bir bilgi kaynağı olarak görülmesi gerekmektedir (Ülger, 2003, s. 240). Gazeteci, kaynağının kendisini yanıltmayacağına, kaynak ise gazeteciye ilettiği haberin çarpıtılmayacağına inanması önemlidir (Yayınoğlu Eraslan, 2013, s. 83). Bu güven zedeleyen bir halkla ilişkiler çalışanı, kendisini dinleyecek ve haberini yayınlayacak medya kuruluşu bulamama gibi bir durumla karşılaşabilmektedir (Çamdereli, 2000, s. 90). Kurumun güvenilir bir bilgi kaynağı olduğunu ortaya koyması, kurumla ilgili asılsız birtakım iddialar ve yapılan haberlerde basın mensuplarının halkla ilișkiler birimine güvenmesine ve itibar etmesine katkı sağlamaktadır (Tarhan, 2013, s. 228). Bu yüzden, kurumlar, medya ile karşııılı anlayışa dayanan iyi ilişkiler kurmalı, gazetecilerin görev ve gereksinimlerini anlayarak, birlikte çalışabilecek ortamlar olușturmalıdır (Gürüz, 1993, s. 57). Halkla ilişkiler çalışanlarının gazetecinin bakış açısını anlamış ve içselleştirmiş olması da gazetecilerle uzun süreli sorunsuz iletişim için şart görünmektedir (Yayınoğlu Eraslan, 2013, s. 83). 


\section{Kriz Dönemlerinde Habercilik}

Kriz dönemlerinde habercilik diğer rutin dönemlere göre daha dikkat edilmesi gereken bir dönem olarak ortaya çıkmaktadır. Kamuoyunda gündem kuran ve kamuoyunu yönlendiren bir faktör olarak önemli yer tutan medya, kriz dönemlerinde büyük bir imtihan da vermektedir. Gazetecilerin (Çaplı ve Taş, 2009, s. 240) krizlerden olumsuz yönde etkilenen kişilerin acil ihtiyaçlarının ve beklentilerinin dile getirilmesi konusundaki sorumluluğu artmaktadır. Bu bağlamda değerlendirildiğinde haber, "var olan her şey", "dün bilmediğimiz her şey", "insanların üzerinde konuştukları şey", "insanların hakkında konuştukları her şey", "ilgimizi çekebilecek, bize ilginç gelen her şey" dir (Aslan, 2002, s. 58) șeklinde tanımlanmaktadır. Daha teknik bir tanıma göre haber "insanları ilgilendiren, temalı olan, bir fikrin ya da sorunun özetidir." (Yüksel, 2006, s. 24). Kriz haberciliği, sosyal, siyasi ya da ekonomik platformlarda yaşanan beklenmeyen tehlike, gerilim ve tehdit anlamın işaret eden habercilik türü ya da uygulamasıdır (Yüksel, 2010, s. 280). Toplumda sıklıkla yaşanmayan, sıra dışılık boyutu ağır basan ve toplumun çoğunluğu tarafından maddi ya da manevi olarak tahrik edici bulunan olaylar, ülke içinde ya da ülkeler arası yaşanan savaş ve çatıșmalar kriz dönemlerini işaret etmektedir (Vural, 2006, s. 143). Gazetecilerin kriz dönemlerini haberleștirirken kamuoyunu nası etkileyeceğini göz ardı etmeden habercilik yapmaları önem taşımaktadır. Çünkü kriz haberlerinde kullanılan görüntüler birey üzerinde psikolojik olarak kalıcı hasarlara neden olabilmektedir. Olağanüstü durumlarda kișiler yoğun șekilde endișe, korku ve panik yaşayabilmektedir. Bu durum bir an önce olan bitenden haberdar olma ve belirsizlikleri giderici kullanışlı bilgiler edinme isteği oluşturmaktadır. Kişiler ilk anlarda aldığı bilgileri eleștirel bir gözle değerlendirmek imkânına sahip olamayabilirler. Böyle ortamlarda duyulan her şeyin "en doğru, en gerçek" olarak kabul edilme eğilimi vardır (Fırat, 2011, s. 38; RTÜK, 2008, s. 96-97). Gazeteciler çabuk ve hızlı haber verme isteği nedeniyle hızı haber verme ile doğru haber verme arasında bir ikileme düșmektedir. Bu kritik eșik, izleyicinin neyi bilmesi ve ne zaman bilmesi gerekiyor? sorularını yanıtlamakla geçilebilir. Olayla ilgili bilgileri doğrulatamadan harekete geçmek, istenmeyen sonuçlara yol açabilme tehlikesi taşımaktadır (Çaplı ve Taş, 2009, s. 247). Kriz haberlerinde sansasyonel sloganlar sürekli tekrar edilmekte, kısa sürede verilebilecek bilgiler görüntü, ses ve müzik efektleriyle birlikte uzun süre yayınlanmaktadır (Fırat, 2011, s. 39). Bu nedenle kriz haberciliği olağandışılığı nedeniyle olağandıșı bir habercilik profesyonelliğini gerekli kılmaktadır (Yüksel, 2010, s. 280; Vural, 2006, s. 144). Kriz haberciliğinde ilk olarak gazetecilerin duygudan çok, bilgi yoğunluklu haberlerin aktarılmasına özen göstermeleri gerekmektedir. Kriz zamanlarında bu tür haberleri abartmadan ve heyecan verici ayrıntılardan sadeleștirerek yalnızca bilgi verici șekilde aktarması önemlidir (İnceoğlu, 2000, s. 348- 349). Kriz döneminde toplumun ve bireylerin ruh sağlığını olumsuz yönde etkileyen, korku ve paniğe yol açacak şekilde yayınlardan kaçınılması gerekmektedir. Bu dönemde kamu yararı, toplumsal sorumluluk ve etik ilkeler göz ardı edilmemelidir (Fırat, 2011, s. 39-49). Kriz dönemleri haberlerini kaos ve paniğe neden olacak şekilde vermek yerine uygun bir dil, doğru zamanlama ve uygun görüntülerle yayın yapılması hasarı azaltacak ve toplum içindeki dayanışmayı arttıran bir davranıs olacaktır (RTUKK, 2008, s. 97). Kriz haberciliğinde kamuoyunu yanlış bilgilendirmemek, olayın ilk ân görüntüleri verilirken görüntülerde seçici davranmak, bu görüntüleri tekrar tekrar yayımlamaktan kaçınmak, kişisel bakıs açısı ve duyguları yansıtmamaya özen göstermek ve mesleki, toplumsal sorumluluk duygularını dikkate almak gerekmektedir (Yüksel, 2010, s. 280). Olağanüstü dönemlerde yayınların nasıl yapılması gerektiği ile ilgili çeșitli etik ilkeler bulunmaktadır. 3984 sayılı Radyo ve Televizyonların Kuruluş ve Yayınları Hakkında Kanun'da yer alan yayın ilkeleri, BBC Yayın İlkeleri Kılavuzu, 1960 yılında yürürlüğe giren Basın Ahlak Yasas çerçevesinde 1988 ylında Basın Konseyi tarafından oluşturulan Basın Meslek Illkeleri, Türkiye Gazeteciler Cemiyeti tarafından açıklanan Gazetecilerin Hak ve Sorumlulukla Bildirgesi, Avrupa Konseyi Parlamenter Meclisi tarafından yayınlanan "Basın Meslek ilkeleri" ve Televizyon Yayıncıları Derneği'nin "Terör ve olağanüstü durumlarda habercilik yapılırken uyulacak İlkeler" gibi pek çok formel-enformel, ulusal-uluslar aras düzenlemeler mevcuttur (Fırat, 2011, s. 108). Avrupa Konseyi Parlamenter Meclisi Basın Meslek Illkeleri'nin 33.maddesine göre, "toplumlarda savaş, terörizm ve azınlıklara karșı ayrım gibi durumlarda tansiyon ve fikir ayrlıkları artar. Böyle durumlarda medya, demokratik hakları ve insani değerleri koruma görevi üstlenmelidir. Medya problemlerin çözümünü için toleranslı ve barışçı yolları savunmalı, şiddete, kültürel, cinsel ya da dinsel herhangi bir ayrıma karşı çıkmalıdır" ilkeleri etik açıdan kriz haberciliğinde de önemli rol oynamaktadır. 2005 yılında gerçekleștirilen kitle iletişim politikaları ile ilgili 7. Avrupa Bakanlar Konferansı'nda bakanlar tarafından "kriz zamanlarında ifade ve haber alma özgürlüğü ile ilgili" karar (Kiev, 2005) kabul edilmiștir. BBC Yayın Illkeleri Kılavuzu'nda 17 bașlık altında çeșitli konular hakkında tavsiye niteliğinde kurallar bulunmaktadır. 2006 yılında bu ilkeler Türkçe olarak yayınlanmıştır. BBC İlkeleri'nin 11. başlığı "savaş, terör ve olağanüstü olaylar" adını almakta ve olağanüstü olayları "sahte ihbarlar, propaganda eylemleri, kaçırma, rehin alma ve işgal olayları, ulusal güvenlik tehditleri, olağanüstü ulusal ve uluslararası olaylar, gösteriler, karışıklıklar ve ayaklanmalar, tehlikeli ortamlar, yüksek riskli faaliyetler ve olaylar" olarak sıralamaktadır (Fırat, 2011, s. 127-128). Avrupa Gazetecilik Merkezi'nin (European Journalism Center-EJC) tarafından hazırlanan ve Türkçe'ye çevrilen "Doğrulama El Kitabı" özellikle gazetecilere açık kaynaklı bilgileri ve kullanıcı üretimi içeriği doğrularken ve kullanırken faydalanabilecekleri bilgiler sunmaktadır. Kitapta bölüm yazarı Steve Buttry, haber yapılacak bilgiye yönelik doğrulamanın kișinin becerikliliği, ısrarı, șüpheciliği ve yeteneği, kaynakların bilgisi, güvenirliliği ve dürüstlüğü ve sayısı, çeşitliliği ve güvenirliği, belgelendirme hususlarına dikkat çekmektedir (http://verificationhandbook.com/ book2_tr/). Buna benzer ilkeler gazetecilerin görevlerini yaparken kamuoyunu doğru bilgilendirme açısından önem taşımaktadır.

\section{Kriz Döneminde Halkla İlișkiler}

Kriz, bir kurumun amacını, hedefini ve yapısını tehdit eden, acil tepki gösterilmesi gereken, öngörme ve önleme mekanizmalarını yetersiz bırakan, kararsızlık ve panik yaratan bir durum olarak tanımlanmaktadır (Can, 2002, s. 333; Çaplı ve Taş, 2009, s. 239). Kurumu bir felakete sürükleyebilen (Demirtaş, 2000, s. 359) bir kavram olarak kriz çoğu zaman olumsuz nitelikteki durumlarla bağlantılı olmasına rağmen (Preselj vd., 2017, s. 229) yeni bilgiler ve deneyimler kazanarak, krizi fırsata dönüştürmek mümkün olabilmektedir. Bu süreçte medya ile ilişkiler önemli 
yer tutmaktadır. Kriz hangi alanda olursa olsun medya ve konuyla ilgili çevreler için önemli bir haber değeri taşımaktadır (Çamdereli, 2000, s. 125-126). Kriz dönemlerinde medya; risk ve tehditler, alınması gereken önlemler, kim, ne zaman, nerede, neler yapıyor, ne yapmalı, nasıl yapılacak gibi soru ve yanıtlar hakkında bilgiyi ilgili her kesime aktarmaktadır (Koç, 2017, s. 27). Kriz dönemi, bilgi isteği talebinin arttığı bir dönemdir. Özellikle insan hayatını tehdit altında bırakan krizlerde bu bilgi ihtiyacı daha fazla önemli hale gelmektedir. Dolayısıyla kriz durumlarında haberciliğin toplumsal önemi artmaktadır. Kriz dönemleri aynı zamanda söylenti, manipülasyon amaçlı konuşmalar ve bilgi kirliliğinin fazla olduğu zamanlar olarak ifade edilmektedir (Çaplı ve Taș, 2009, s. 239). Kriz dönemlerinde gazeteciler olabildiğince fazla bilgi edinmeye çalıșırken, halkla ilișkiler çalıșanı imajı olumsuz yönde etkileyen haberleri en aza indirmeye çalışmaktadır (Arpan ve Pompper, 2003, s. 291). Ancak kriz dönemlerinde (Koç, 2017, s. 36), olaya dayalı "doğru ve tarafsız" haber enformasyonu için haber kaynaklarının doğru seçimi, ulaşımı ve haberde kullanımı özellikle olağanüstü durumlar açısından önem taşımaktadır. Kriz dönemlerinin medya tarafından topluma sunulması daha fazla okur, daha fazla izleyici anlamına gelmektedir. Bu süreçte halkla ilişkiler çalıșanlarının medya organlarını ilk ama doğru bilgilendiren olması çok önemli hale gelmektedir. Bu durum, önlemler alınmadığı zaman telafis güç iletişim hatalarına neden olabilmektedir (Demir, 2015, s. 354). Gazeteciler ile halkla ilişkiler çalışanları arasındaki ilişki rutin dönemlerde olduğu gibi kriz dönemlerinde de iki yönlü simetrik halkla ilişkiler uygulaması modeli, kuruluşlar ve paydaşları arasındaki olumlu ilişkileri teşvik etmek için ideal bir araç olarak önerilmiştir (Grunig, Grunig ve Dozier, 2006). Model, paydaşları anlama ve daha sonra karşılıklı yararlı sonuçlara ulaşmak için çalışmalara prim vermektedir. Medya ilișkileri bağlamında bu, gazetecileri dinlemeyi, intiyaçlarına cevap vermeyi, kuruma erişimi sağlamayı ve gazetecilerin istedikleri biçimde intiyaç duydukları faydalı bilgileri sağlamayı gerektirir (Grunig ve Hunt, 1984). Iki yönlü simetrik uygulamanın bir yararı, bir kurum ve halk arasında diyalogu teşvik etme potansiyelidir. Diyalog iletișimi "müzakere edilen herhangi bir fikir ve görüş alışverişini" temsil eder (Kent ve Taylor, 1998, s.325) ve karşılıklı anlayıs üzerine inşa edilen tatmin edici, uzun vadeli ilişkilerin oluşumuna katkıda bulunur. Halkla ilişkiler pratisyeni-gazeteci diyalektiğinin kişilerarası dinamikleri, profesyonellik, dürüstlük ve diyalog uygarlığı tarafından desteklenen bir anlatı yapısı oluşturur. Yalnızca duygusal duygulara dayanan bir ilişkinin aksine, halkla ilișkiler pratisyenleri ve gazeteciler arasındaki kişilerarası etkileșimler, haber değeri taşıyan ve halkın ilgisini çeken medya içeriği oluşturmak için üretken bir hedefe doğru çalışır. Bu çalışma ilişkisi - değişme, gelişme ve bozulma yeteneğine sahip - başarılı halkla ilișkiler uygulayıcısı ile gazeteci söylemi arasındaki iletișimse değișimin temelidir (Langett, 2013, s. 9). Gazeteci ile halkla ilișkiler arasındaki ilișkinin düzeyini belirlemek amacıyla birçok çalışma yapılmıştır.

Gazetecilerin 5 yıllık süre içerisinde halkla ilișkiler uygulamalarıyla ünlü ve 2005 yılında en çok beğenilen havayolu şirketi olarak Fortune 500 şirketi arasında yer alan Southwest Airlines'in medya ilişkileri çabalarına ilişkin algılarını incelemek amacıyla yapılan çalışmada şirketin halkla ilişkiler etkinliği, medya ilişkileri değeri ve diyaloglu iletişim stratejileri (bilgi, erişilebilirlik, yanıt verebilirlik) algıları ölçülmüștür (Callison ve Seltzer, 2010). Callison ve Seltzer (2010), șirketin 24 saat danışma hattını çalıştırması, halkla ilişkiler çalışanlarına kolaylıkla ulaşıması, çevrimiçi kaynakların çok başarılı kullanılması, gazetecilerin intiyaç duyduğu bilgilere kısa sürede ulaşmaları ve geri tepkilerin çok hızlı şekilde sonuçlandırması gazeteciler tarafından olumlu olarak algılanmıştır.

Yapılan çalışmada kriz tecrübesi olan 214 Hollandalı gazeteci ile görüşülmüştür. Çalışmada gazetecilerin haber kaynaklarında güvenilirlik, bilgi, isteklilik, zamanındalık ve gazeteci ile ilişkinin belirleyici olduğu, normal şartlardan daha fazla, bir kriz sırasında, haberlerin çoğunlukla kaynaklar tarafından sağlanan bilgilerden oluştuğu, bu nedenle, kaynak seçiminin kapsamlı bir şekilde anlaşılması, bir kriz sırasında haber kapsamının nasıl oluşturulduğunu ve izleyicinin haber medyası kullanarak bilinçli kararlar verebildiğini keşfetmek için çok önemli olarak değerlendirilmektedir Bir krizin kapsamında birden fazla kaynağın çok önemli bir rol oynayabileceği kabul edilmektedir. İyi kaynakların önemi yalnızca güvenilir ve bilgili olmaları değil, aynı zamanda zamanında konuşmaya ve iletişim kurmaya istekli olmalarından gelmektedir Bu nedenle, gazetecilerin iyi ilișkiler içinde olduğu kaynaklar otomatik olarak uzman olarak görülebilir ve böylece daha güvenilir ve bilgili olarak algılanabilir. Bu nedenle kaynak-gazeteci ilişkisinin kriz sırasında kaynağın dâhil edilmesi üzerinde dolaylı bir etkisi olduğu söylenebilir. ilişki daha güçlüyken, bir gazeteci kaynağı güvenilirlik ve bilgi açısından daha olumlu değerlendirecek ve bir kaynak zamanında yorum yapma ve iletişim kurma konusunda daha istekli olacak, sırayla haber kaynağı olma olasılığını artıracaktır (van der Meer vd., 2017, s. 1112). Lewis, Williams, Franklin, Thomas ve Mosdell (2008) tarafından yapılan bir araștırma, gazete hikâyelerinin \% 19'unun ve yayın hikâyelerinin \% 17'sinin en çok halkla ilişkilerden geldiğini ve hikâyelerin yarıdan daha azının halktan bağımsız olduğunu göstermektedir. Davies (2009), İngiltere'nin en iyi bes gazetesinde bildirilen haberlerin \% 60'ının halkla ilișkiler ajanslarından veya elektronik kopyalardan geldiği bir çalıșmayı bildirmiștir. Sissons (2012), gazetecilerin gündem belirleyici rollerini yitirmeleri için halkla ilişkilerin gazetecilik üzerindeki etkisinin arttığına dair araştırma kanıtları konusundaki endişeleri bildirmektedir. Sissons'a göre neredeyse veya tamamen değișmeden haber haline getirilen halkla ilișkiler çIışanları tarafından hazırlanarak sunulan basın bültenleri konusunda habercilerin ve haber tüketenlerin endişeli olmaları gerekmektedir.

Kriz döneminde kurumlar açısından ayrıca kriz yönetimi devreye girmektedir. Kriz yönetimi, kuruluşun politikasını belirleyen bir yönetim görevi olması ve kurumun iletişimini belirleyici özellik taşıması nedeniyle halkla ilişkilere büyük ihtiyaç duymaktadır (Akdağ, 2005, s. 1). Krizin en az zararla atlatılabilmesi için yöneticilerin, ilk olarak krize neden olan problemleri tespit etmesi ve zaman kaybetmeden halkla ilişkiler çalışmalarına başlamaları gerekmektedir. Bu nedenle krizde halkla ilişkiler calıșmaları normal zamandan daha çok önem kazanmakta, kriz dönemlerinde karara katılan ve uygulamaya doğrudan müdahale edebilen bir birim olarak ortaya çıkmaktadır (Akdağ, 2005, s. 2; Kazancı, 1996, s. 308). Charron (1989, s. 50) halkla ilişkiler açısından gazetecilerle sadece belirli bir zamanda ișbirliğinin medya ile gelecekteki ilişkilere ciddi şekilde zarar verebileceğini, özellikle kriz dönemlerinde medyadan 
kaçınmanın krizi kabul etme olarak değerlendirilebileceğine dikkat çekmektedir. Kriz yönetim ekibi gerekli bilgi intiyacını gidermediği takdirde, medya başka kaynaklara yönelmekte, doğru ve gerekli bilginin sağlanmaması durumunda haber kuruluşları ortaya çıkan boșluğu kendi yöntem ve kaynaklarıyla doldurmaya çalışmakta, haber kaynağı olarak daha bilgisiz, yetersiz, güvenilir olmayan kaynaklara yönelebilmektedir (Pira ve Sohodol, 2004, s. 223). Bu olumsuz durumları yaşamamak için kriz ve iletisim merkezi kurulmalıdır. Bu yapılanmanın amacı, kamuoyunu bilgilendirmektir. Bu örgütlenmenin, olay hakkındaki bilgilerin düzenli olarak toplandığı, günün her saatinde bilgi akışının sağlandığı, söylenti ve dedikoduların yanıtlandığı, düzenli bilgilendirme ve basın toplantılarının yapıldığı ve bir sonraki toplantının medyaya bildirildiği bir ișleyiş olması gerekmektedir (Çaplı ve Taş, 2009, s. 242-243). Böyle bir ortamı yaratmak için medya mensuplarının gün içinde istedikleri zaman bilgi alabilmelerini sağlayacak bir sistem geliştirilmelidir. Bunun için acil medya merkezi kurularak, bu merkezde olayın neden ve sonuçları hakkındaki bilgilere sahip, tam donanımlı kişilerin medyadan gelen soruları büyük bir titizlikle yanıtlaması sağlanmalıdır. Medyadan gelecek kişilerle iletişimin sağlanması için basın toplantılarının düzenlenebileceği bir basın odası hazırlanmalı, basın odasında medya mensuplarının intiyaç duyabileceği materyaller hazır bulundurulmalıdır (Akım, 2005, s. 173). Özellikle kriz durumunda hiçbir medya kuruluşuna ayrıcalık ve öncelik sağlanmamalıdır. Böyle bir durum rekabet kaygısı, hatalı ve spekülatif bir haber üretim sürecine zemin hazırlayabilmektedir (Çaplı ve Taș, 2009, s. 243). Endişeye kapılmış bir hedef kitleyle iletişim kurulduğunda bu kitlenin kuruluşun üstesinden zor gelebileceği güçlü bir tutum engeliyle karşılaşma durumu vardır. Hedef kitleye verilecek mesajlarda ve alınan önlemlerde bu engeli aşmaya yönelik çalışmaların kuruluş tarafından yapılması gerekmektedir (Okay ve Okay, 2014 s. 398). Kurumdan yetkili birisi açıklamalarda veya krizin olduğu yerde bulunmalıdır. Medyada krizle ilgili verilen haberler takip edilmeli, eksik ve hatalı bilgiler varsa düzeltilmelidir. Çünkü böyle bir davranış kurumun krizi çözmek için konuya gösterdiği ilgi ve çabayı kamuoyuna göstermeye yardımcı olmaktadır (Akım, 2005, s. 174). Kriz iletişim ekibinde, halkla ilişkiler yöneticisi ya da sorumlusu, finans müdürü, hukukçu, hissedar, pazarlama ve reklam sorumlusu, veri işletim ve büro hizmetlerinde çalışan eleman bulunmalıdır (Okay ve Okay, 2014, s. 390). Kriz ya da medya sözcüsünün doğru kişi olması ve bu kişinin etkili olması önemlidir. Bu kişi aynı zamanda doğru bilgiyle donatımalı ve mutlaka kriz eğitimi almalıdır. Bu eğitim basın becerilerini geliştirecek ve muhtemel kriz senaryolarının uygulanma biçimlerini algılamalarına katkıda bulunacak şekilde hazırlanmalıdır (Akım, 2005, s. 175). Johnson \& Johnson şirketi, 1982 'de Tylenol ürünü ile ilgili yaşadığı kriz karşısında hızı tepki göstermesi ve proaktif çalıșmalar sayesinde kurumun itibarını başarılı bir yönetim ile korumuştur (Cravens ve Oliver, 2006, s. 295). Bu nedenle halkla ilișkiler biriminin, bir erken ikaz sistemi gibi kurumu önceden uyaracak şekilde çalışması gerekmektedir (Grunig ve Hunt, 1984, s. 57). Krizde halkla ilişkiler çalışanlarının kontrolünde olan ve olmayan durumlar söz konusu olabilir. Kuruluşun web sayfasında yer alan hikâyeler kuruluşun kontrolü altındadır (Coombs ve Holladay, 2009, s. 5) ve bu durum krizi az hasarla atlatmaya yardımcı olabilmektedir. Kriz dönemlerinde kurumun itibarının korunması da önemli hale gelmektedir. Etkin bir kriz yönetimi, kurumların itibar kazanmalarını ya da var olan itibarlarını güçlendirmelerinde etkilidir. İtibar risk yönetim sürecinde kurumsal itibarın korunması için açık ve dürüst bir șekilde paydașlarla iletişim kurulmalıdır (Joosub, 2006, s. 30-31; Uzunoğlu ve Öksüz, 2008, s. 114- 120). Bu amaçla kriz yönetiminde etkili bir iletişimin kurulması için önlemler alınmalı, kriz yönetiminde medya ile ilişkiler iyi yönetilmeli, krizi yönetmek için bir internet sitesi olușturulmalı ve kriz süresince öncelikli olarak aşağıdaki noktalara dikkat edilmelidir (Peker ve Aytürk, 2000, s. 394; Göztaş, 1997, s. 35-36; Kadıbeşegil, 2001, s. 113-114; Weiner, 2006, s. 3-5; Holtz, 1999, s. 200; Demir, 2015, s. 351):

Kriz yönetim planı oluşturulmalı ve plana bağlı kalınmalıdır.

Krizde alınan kararlar görevli personele iletilmelidir.

Krizde iletişim kurulacak yetkililerin listesi hazırlanmalıdır.

Bir internet sayfası oluşturmalı, kurumun pozitif algısı oluşturulmalı ve korunmalıdır.

Toplumsal hassasiyetleri dikkate alan, yanlış anlaşılmaları ortadan kaldırmaya yönelik stratejik söylemler kriz öncesinde hazırlanmalıdır.

Kriz sözcüsü, basına ve kamuoyuna abartılı, yanlış, gerçek dışı haberlere karşı aydınlatıcı açıklamaları zamanında yapılmalıdır.

Dürüst olunmalı ve hatalar kabul edilerek özür dilenmelidir.

Medyaya bilgi verirken bilginin hedef kitleye verildiği unutulmamalıdır.

Kriz dönemlerinde en önemli çalışma iletişim planlamasıdır. Dolayısıyla medya ile ilișkilerin yürütülmesinde önceden hazırlanan kriz planı ve olușturulan kriz birimi önemli rol oynamaktadır. Doğru bilgileri verebilmek ve yanlış bilgileri süzebilmek için bilgilendirmenin kriz birimi tarafından yapılması en uygun yöntemdir. Örgütü medyaya karşı kimin temsil edeceği, basın toplantılarının sorumluluğunu kimlerin alacağı, üst düzey yöneticilerinin medya ile ilişkilerinde ne tür sınırıııklar olacağı, hangi bilgilerin ne zaman ve hangi yöntemlerle açıklanacağı, haber kuruluşlarıyla ilişki sıklığı iletişim planında belirlenmelidir (Kazancı, 2002, s. 290). Ayrıca halkla ilișkiler çalışanlarının işlerini yaparken uymak durumunda oldukları meslek ilkeleri bulunmaktadır. Günümüz halkla ilişkiler mesleğinin kurumsal sosyal sorumluluk ve medya ile ilişkiler gibi alanlarında evrensel etik kuralların kurumlar arası ve kültürlerarası farklııklar gözetilerek içselleştirilmesi gerektiği savunulmaktadır (Hürmeriç, 2016, s. 407). Bu bağlamda halkla ilişkiler meslek ilkelerini ortaya koyan çeşitli düzenlemeler oluşturulmuştur. IPRA'nın Meslek Ahlak Yasası'nda, halkla ilişkilercinin kamusal sorumluluğu, "bir üye daima kamuoyunun çıkarları doğrultusunda hareket etmelidir." ifadesiyle belirtilmektedir. Türkiye İletişim Danışmanlığı Şirketleri Derneği'nin Meslek Ahlakı İlkeleri'nde, iletişim danışmanları, "hizmet ettikleri kişi, kurum ve kuruluşların temsili sürecinde, ilgili tüm tarafların ve kamunun çıkarlarını da göz önünde bulundururlar, kamuoyu ve ilgili taraflarla kurdukları iletişimde; doğru bilgi aktarımına özen gösterirler, aktardıkları ancak daha sonra doğru olmadığını öğrendikleri/anladıkları bilgilerle ilgili yanlışlarını düzeltirler" ilkesi yer almaktadır. Roma Bildirisi'nde "Dernek üyesi şirket, mesleki etkinliklerini kamu çıkarına gereken saygıyı göstererek yürütecektir" ve ayrıca Halkla ilişkilerci, "gerçeğe saygı göstermekle, bilerek ya da düşünmeden yalan ya da yanlış yönlendirilen bilgi yaymakla ve kasıtlı olmadan böyle bir davranışta bulunmaktan kaçınmak için gereken dikkati göstermekte her zaman yükümlüdür." (Uzun, 2007, s. 192). Lizbon Yasası'nda (1978) halkla ilişkileri uzmanı mesleki davranışlarında doğruluk, dürüstlük 
ve düşünsel namus gözetmelidir" mesleki zorunluluklar maddesinde yer almaktadır. Helsinki bildirgesinde halkla çalışanının meslek için oluşturulan standartları bilmesi gerektiği vurgulanmıştır (Okay ve Okay, 2014, s. 616). Gazetecilerin ve halkla ilişkiler uygulayıcılarının mesleki etik kodlara göre mesleklerini yapmaya yönelik çabaları her iki mesleğin temsilcilerinin ilişkilerini belirleyici faktör olarak ortaya çıkmaktadır.

\section{Araştırmanın Yöntemi}

Araştırmanın soruları şu şekildedir ve araştırma sorularına derinlemesine görüşme ile yanıt aranacaktır.

Gazetecilerin kriz dönemlerinde halkla ilişkiler çalışanlarına bakıș açısı nasıldır?

Gazeteciler kriz eğitimi almış mıdır?

Gazeteciler halkla ilişkiler çalışanlarını iyi bir haber kaynağı olarak görmekte midir?

Krizde halkla ilişkiler çalışanları ile gazetecilerin rolü nedir?

Gazetecilere göre kurumlar krizden nasıl etkilenmektedir?

Krizde liderin rolü nedir?

Araștırma soruları ile birlikte bu çalıșmanın amacı, kriz dönemlerinde gazetecilerin halkla ilişkilere bakıș açısını ve beklentilerini ortaya koymaktır. Çalıșma kapsamında yerel medyada çalışan gazeteciler ile derinlemesine görüşme yapılmıştır. Derinlemesine görüşme, herhangi bir araştırma konusunun bütün boyutlarını kapsayan, açık uçlu soruların sorulduğu ve detaylı cevapların alınmasını sağlayan, yüz yüze görüşülerek bilgi toplanılan bir veri toplama tekniğidir (Tekin, 2006, s. 101). Başka bir ifadeyle derinlemesine görüşme, bireylerin tecrübelerine, görüşlerine, duygularına ve inançlarına ilișkin bilgi elde etmede etkili bir yöntem olarak tanımlanmaktadır (Sevencan ve Çilingiroğlu, 2007, s. 4). Bu bağlamda 21 gazeteciye 16 soru yöneltilerek derinlemesine görüşme gerçekleştirilmiştir.

Görüșme yapılan kișiler seçilirken tecrübeli olmaları ve en az bir kriz durumunu haberleştirmiş olmalarına dikkat edilmiştir. Çalışmada gazetecilerin tercih edilme nedeni haberi kaynaktan alarak ilk haberleştiren kişi olmalarıdır. Ayrıca kriz dönemlerinde gazeteciler kurumlarla ilk iletișim kuran kişilerdir. Bu nedenle gazetecilerin kurumda önemli bir görevi üstlenen halkla ilişkiler çalışanlarına bakış açıları, onları bilgi kaynağı olarak görüp görmedikleri ve bilgiyi nereden alarak haber hazırladıkları önem taşımaktadır. Kamuoyunu bilgilendiren gazetecilerin bilgileri nereden ve nasıl alarak haber hazırladıkları kamuoyunu doğru bilgilendirmek açısından da önemlidir. Çalışmada, kadın gazetecilerin az olmasının nedeni özellikle medyada çalışan kadın sayısının azlığından kaynaklanmaktadır. Görüşme e-posta, telefon ve yüzyüze görüșme ile gerçekleştirilmiştir. Araştırma soruları, gazetecilik bölümü akademisyenlerinden destek alınarak ve literatür taraması yapılarak hazırlanmıştır. Çalışmayı kolaylaştırmak amacıyla kodlama G1, G2 ..., G19, G21 şeklinde yapılmıştır.

\section{Bulgular}

Çalışma için 16 erkek, 5 kadın olmak üzere 21 gazeteci ile görüşülmüştür. Gazetecilerin yașları 21 ile 48 arasında değișmektedir. Görev dağılımı 1 kameraman, 3 yazı işleri müdürü, 3 editör, 1 baş muhabir, 2 bölge müdürü, 11 muhabir şeklindedir. 10 bekâr ve 11 evlidir. 1 lise, 1 yüksekokul, 3 yüksek lisans, 1 doktora, 15 üniversite (lisans) mezunudur. 15 gazeteci iletişim fakültesi mezunu, diğer 6 kişi de farkı bölümlerden mezundur. Gazetecilerin meslek hayatlarındaki deneyimleri 7 ay ile 28 yıl arasında değişmektedir.

\section{Kriz eğitimi}

Gazetecilerin kriz ile ilgili eğitim alıp almadıkları sorusuna \% $57(n=12)^{\prime} i$ hayır, \% 43 (n=9)'i evet yanıtını vermiştir.

Tablo 1: Gazetecilerin kriz ile ilgili eğitim durumu

\begin{tabular}{|l|c|c|}
\hline & Sayı & Yüzde \\
\hline Evet & 9 & $\% 43$ \\
\hline Hayır & 12 & $\% 57$ \\
\hline Toplam & 21 & 100.0 \\
\hline
\end{tabular}

Gazetecilerin kriz dönemlerini daha bilinçli hazırlamaları için kriz eğitimi almaları önem taşımaktadır.

\section{Kamu menfaatinde işbirliği yapılması}

Kriz dönemlerinde gazeteciler özellikle kamu menfaati söz konusu olduğunda işbirliği yapmalıdır görüșüne hâkimdir ancak bu işbirliğinin objektifliğe dikkat ederek, sosyal sorumluluk ve gazetecilik etiği çerçevesinde yapması gerektiği belirtilmektedir.

Tablo 2: Kamu menfaatinde gazetecilerin işbirliği

\begin{tabular}{|c|c|c|}
\hline & Sayı & Yüzde \\
\hline Yapılmalıdır & 21 & 100 \\
\hline Yapılmamalıdır & 0 & 0 \\
\hline Toplam & 21 & 100.0 \\
\hline
\end{tabular}


Gazetecilerin kamu menfaati söz konusu olduğunda ișbirliği yapılmalıdır görüşü bu konuda toplumsal hassasiyete dikkat edildiğini göstermektedir.

\section{Haber kaynağı}

Gazeteciler halkla ilişkiler çalışanlarının iyi bir haber kaynağı olup olmadığı ile ilgili soruya \% $38(n=8)$ evet, \% $23.9(n=5)$ hayır, \% $14.4(n=3)$ her zaman değil, \% $19(n=4)$ olması gerekir ve \% $4.7(n=1)$ kuruma göre değişir şeklinde yanıt vermişlerdir.

Tablo 3: Halkla ilişkiler çalışanının haber kaynağı olması

\begin{tabular}{|l|c|c|}
\hline & Sayı & Yüzde \\
\hline Evet & 8 & $\% 38$ \\
\hline Hayır & 5 & $\% 23.9$ \\
\hline Her zaman değil & & $\% 14.4$ \\
\hline Kuruma göre değişir & 3 & $\% 4.7$ \\
\hline Olması gerekir & 1 & $\% 19$ \\
\hline Toplam & 4 & 100.0 \\
\hline
\end{tabular}

Gazetecilerin halkla ilişkiler çalışanlarını \% $38(n=8)$ oranında bilgi kaynağı olarak görmesi her iki tarafın ilişkilerinin önemli olduğunu ortaya koymaktadır. Ancak önemli bir haber kaynağı olarak görülmemesinin de sorgulanması gerekmektedir.

\section{Krizi haberleştirirken yaşanılan zorluklar}

"Yetkililer doğru bilgiyi kamuoyuyla paylaşmaktan çekiniyor. Gerçeklerin gizlenmesi, açıklanmasının ertelenmesi, gerek yetkililerin gerekse insanların kriz durumunda olduğunu inkâr etmesi ciddi zorluklar arasında yer almaktadır" (G1, G2, G3, G4, G5, G9, G10, G11, G12, G13, G15, G19, G20)."Basın metinlerinin eksik ve doğru bilgiyi vermesinde bir zorluk yaşanıyor" (G14)."Soğukkanlı olmayı sürdürülebilir kılmak ciddi anlamda zor bir hadise" (G18). "Kurum ve kuruluşlardaki yetkililerin habere konu olan açıklamalarını teyit noktasında zorluk yaşadım, kaynağınızın güvenirliliği ve doğruluğu hususunda endişelerimiz oluyor" (G21).

Gazeteciler, kriz dönemlerinde yetkililerin gerçeği açıklamaktan çekindiklerini, habere konu olan olayla ilgili bilginin doğruluğu ya da yanlışlığı konusunda onay alamadıklarını vurgulamaktadır. Bu durum gazetecilerin kısa sürede doğru bilgiye ulaşmasını engellemektedir.

\section{Gazetecilerin yeterli bilgiye zamanında ulaşması}

Gazetecilerin kriz dönemlerinde yeterli bilgiye ulaşma durumuna bakıldığında gazetecileri \% $52.4(n=11)$ 'si hayır yanıtını verirken, \% $14.4(n=3)^{\prime}$ 'i kuruma göre değişir, \% 9.5 ( $n=2)^{\prime}$ 'u çoğu zaman ulaştıramıyorlar, \% $9.5(n=2)^{\prime}$ u bazen aksaklıklar oluyor, \% $9.5(n=2)^{\prime}$ u geç kalıyorlar, \% $4.7(n=1)^{\prime} i$ ulaştırmaları gerekir şeklinde yanıt vermiştir.

Tablo 4: Gazetecinin yeterli bilgiye zamanında ulaşması

\begin{tabular}{|l|r|c|}
\hline & Sayı & Yüzde \\
\hline Evet & 0 & $\% 0$ \\
\hline Hayır & 11 & $\% 52.4$ \\
\hline Ulaştırmaları Gerekir & 1 & $\% 4.7$ \\
\hline Geç Kalıyorlar & 2 & $\% 9.5$ \\
\hline Bazen aksaklık oluyor & 2 & $\% 9.5$ \\
\hline Çoğu zaman ulaştırmıyorlar & 2 & $\% 9.5$ \\
\hline Kuruma göre değişir & 3 & $\% 14.4$ \\
\hline Toplam & $\mathbf{2 1}$ & $\mathbf{1 0 0 . 0}$ \\
\hline
\end{tabular}

"Kurumsal alt yapısını olușturan ișletmelere ulașmak çok da zor olmuyor" (G1). "Bilgiler yetersiz ve geç geliyor, haberciler diğer kaynaklara yöneliyor" (G4). "Kurumun, kurumsallaşma durumuna göre değişiklik gösteriyor" (G5). "Bazı durumlarda yeterli bilgi zamanında ulaşmıyor. Bu yüzden basında da çok sayıda yanlış haberler çıkmaktadır" (G9). "Kurumdan kuruma değişiyor ancak çoğunlukla yeterli bilgiyi ve doğru bilgiyi zamanında ulaştıramıyorlar" (G11). "Hayır veremiyorlar. Nedeni ise üstlerinden alacakları bilgiyi beklemeleri ve gazetecilere verecekleri bilgi notlarını onaylatmalarıdır. Bu süreç zaman kaybına yol açmakta ve kurumu çoğunlukla olumsuz olarak etkilemektedir" (G19)."Genellikle geç kalmış oluyor" (G20)."Krizi iyi yönetebilecek böyle bir bilgi ve tecrübeye sahip halkla ilişkiler çalışanı bulamazsınız. Şu anda bile normal süreçte halkla ilișkileri sağlayacak çalıșanların büyük çoğunluğu, sanki halka çelişkiler birimi gibi çalışmaktadır. Bu kurumsallaşamamak ve kurumsal yapıya uygun elamanların atanmamasından veya çalıştııımamasından kaynaklanıyor"(G21).

Doğru bilginin zamanında gazetecilere ulaşmaması, yanlış bilgilerle haberin kurgulanmasına neden olmaktadır. Gazetecilere göre, krizi iyi yöneten kurumlar aynı zamanda kurumsallaşmasını tamamlamıştır. Krizi yönetemeyen kurumlar kurumsallașma sürecini tamamlamamıs ve kurumsal yapıya uygun ve tecrübeli halkla ilişkiler çalışanı istihdam etmemeleri nedeniyle zorluk yaşamaktadır. Halkla ilişkiler çalışanları aynı zamanda kriz dönemlerinde gazetecilere iletecekleri bil- 
gileri üst yönetime zamanında onaylatamamaları nedeniyle geç kalmaktadır. Bu durum gazetecilerin bilgiyi alırken zaman kaybetmelerine yol açmaktadır.

\section{Halkla ilişkiler birimlerinin hataları}

“Olaya tam hâkim olmuyorlar. Gerekli donanıma sahip olmayan insanlar işin başında olduğu için krizi yönetmekten ziyade savaş ortamına dönüștürerek tam bir sarmal haline getiriyorlar. Beklentilere göre cevap veremeyen tecrübesiz elemanlar işleri daha da çıkmaza sokuyor" (G2, G7)."Bazı kuruluşlara bilgi verip bazı kuruluşlara bilgi vermeme yolunu tercih etmektedirler. Bilgilerin teyit edilmesi konusunda da yetersiz kalmaktadır" (G4). "Kurumların kendi içinde herhangi bir kriz yönetimi oluşturulmadığı için, halkla ilişkiler bölümleri de kriz yönetimini ne kadar istese de yapamıyor. En başta, kendi kurumlarının eksik ve yanlışlarını örtbas etme adına yanlış ve taraflı bilgiler paylaşıııor, insanlar manipüle ediliyor. Ayrıca insanların doğru bilgiye ulaşmaları da engellenmek isteniyor. Gerekli açıklamalar yapılmıyor" (G5)."Gazetecilere mobbing uygulamaya çalışıyorlar. Gazetecileri değil gazete patronlarını arıyorlar" (G9)."Genellikle kriz durumunda büyük sermaye sahiplerini deli gibi savunup haklı çıkarmaya çalışıyorlar" (G10)."Gazetecilere sundukları bilgiler konusunda hatalar yapabiliyorlar. Bu da gazetecilerin prestijini olumsuz etkiliyor" (G11)."Olayı gizlemek isterken bilgi kirliliklerine neden olup, kamuoyunun yanılmasına neden oluyorlar. Oncelikle kamuoyunun merak ettiği konularda bilgi vermekten kaçınmaları en büyük hata. Onlar zamanında bilgi vermediği için gelişen iletişim çağında bilgi kirliliği hızla yayılıyor, küçük bir kriz büyüdükçe büyüyor. Bu bakımdan önce doğru bilgi vermeleri gerekir» (G1, G3, G12, G13, G14, G15, G16, G18, G19, G20)."En başta krizi yönetemiyorlar. Yanlış yönlendirme veya farkında olmadan hatalar yapıyorlar. Öngörememe" (G21).

Gazeteciler halkla ilişkiler çalışanlarının bilgiyi gizlemeye çalıştıklarını, yanlış ve eksik bilgi vererek kamuoyunu yanılttıklarını, bu yanlış ve eksik bilgi nedeniyle krizi daha da büyüttüklerini ifade etmektedir.

\section{Halkla ilişkiler çalışanın aktör olması}

“Cesareti olmayan kurumların halkla ilişkiler birimi açıklama yapılmaması gerektiğini düşünür. Krizin ülke için ne demek olduğunu, vatandaşlar için hangi riskleri ifade ettiğini bilen halkla ilişkiler çalışanları ise gazetecileri yönlendiren bir tutum sergiler"(G1)."Genellikle oluşabilecek krizi en az hasarla atlatmaya çalışan bir aktör diyelim. Yapıcı gibi görünüp, kurumunun menfaatini gözetmeye gayret ederler" (G2)."Ben yönlendiren bir aktör olması gerektiğini düşünüyorum, haberi engellemekten daha çok haberin doğru ve art niyetsiz medyada yer alması önemli" (G3, G4, G6, G8, G9, G10,G11, G12, G13, G14, G16, G19)."Kriz durumu o kurumu olumsuz gösterecek bir durumsa kesinlikle engelleyen bir faktör oluyor." (G5, G21)."Hiçbiri" (G7). "Çoğu birimde engelleyen faktör" (G15)." Her ikisi de olabilir kuruma ve görüşe göre değişir" (G17). "Ikisi de olmamalı diye düşünüyorum" (G18). "Bilgiyi teyit etmede faydalı bir aktördür" (G20).
Halkla ilișkiler çalışanı, doğru bilgiyi vererek gazeteciyi doğru haber yapmaya yönlendiren ve krizi kurumun en az hasarla atlatmasını sağlayan bir aktör olmalıdır. Gazeteci kriz dönemlerinde halkla ilişkiler çalışanlarından doğru bilgi talep etmektedir. Gazeteciler aynı zamanda halkla ilişkiler çalışanlarının doğru bilgi vererek kurumlarını kamuoyuna daha doğru tanıttıklarını düşünmektedir.

\section{Halkla ilișkiler biriminin rolü}

"Birimin rolü herkese eşit şekilde bilgi vermek ve kamuoyunun krizden en az seviyede etkilenmesini sağlamaktır"(G4). "Kriz dönemlerinde basına ne kadar büyük görev düşüyorsa, kurumların halkla ilişkiler birimlerine de o kadar görev düşmektedir. Doğru bilgiye, en kısa sürede ulaşılabilmesi için gazetecilere yardımcı olmaları, gazetecilerle yöneticiler arasında doğru bir köprü vazifesi görmeli, adeta bir emniyet sübapı gibi olmalılar" (G1, G2, G3, G5, G6, G8, G9, G10, G11, G14, G15, G17, G18, G19, G20)."Olmalıdır. Rolü ise, yön vermeden ziyade birlikte ortak fikirler kurarak, kriz en aza nasıl indirgenir bunun yöntemleri aranabilir" (G7)."Her ne șekilde olursa olsun, bedelini düšünmeden belgeleri kamuoyuna sunmalıdır. Gerçeklerin ortaya çıkmasına destek veren kiși ve görevliler her zaman korunmalı, hatta ödüllendirilmelidir" (G12). "Insanları anlamaya çalışmalı ve gazetecileri mesleki yönden insani yöne doğru yönlendirmeli" (G16)." illk tercih edilen kaynak olmalılar, bunu sağlayacak altyapı hazır olmalı, tecrübeli, bilgi birikimine sahip, öngörüsü yüksek kişiler olmalı" (G21).

Gazetecinin mesleğin verdiği sorumluluk gereği kriz dönemlerinde toplumu panikletecek, krizin daha da büyümesine neden olabilecek haber yapmaktan sakınması beklenmektedir. Bu sorumluluğun yerine getirilmesi için halkla ilişkiler çalışanına da görev düşmektedir. Halkla ilişkiler çalışanı, gazeteciler ile yöneticiler arasında bir köprü vazifesi görerek, gazetecilerin doğru bilgiye kısa sürede ulaşmasını sağlamak için çaba harcamalıdır.

\section{Krizden önceki çalışmaların krize etkisi}

“Etkiler çünkü geçmiş birikimleri haberciler için etkileyici bir unsurdur. Önceki dönemlerde söz konusu kurumlardan yapılan basın açıklamaları gazeteci için belirleyici olabilir. İyi ilişki kurulmuşsa iyi, kötü ilişki kurulmuşsa kötü. Krizden önce güvenilir bir çalışan bilgileri teyit gerektirmeyen bir çalışan kriz döneminde de haber yapılma sürecini kolaylaştırmaktadır. Halkla ilişkiler çalışmaları kimlik oluşturmada da kullanıldığı için kriz durumunda geçmişe dayanarak kanaat oluşturulur(G1, G3, G4, G6, G9, G10, G11, G13, G14, G16, G18, G20)."Krizi etkilemekten ziyade ilerleyen süreçte krizin izleyeceği yolda belirleyici olabiliyor" (G2). "Bu birimin kriz durumlarına ne kadar hazırıkklı olmalarına bağlı olarak değişiyor. Kimi kurumda bu birimin sadece tabelası bulunurken, bazı kurumlarda oldukça aktif olarak hizmet vermekteler. Ancak bu aktiflik, kriz dönemlerinde pasif duruma düşmemeli"(G5)."Etkilemiyor" (G7, G8, G12, G15, G17)."Hayır etkilemiyor. Çünkü önemli olan yașanan bir durumu kamuoyuna bildirmek. Önceki çalışmalar geçmişte kalmıştır ve olağanüstü 
bir durum ortaya çıkmıștır. Burada gazetecilik refleksi ön plana çıkar" (G19). "Alanında uzmanlaşmamış, başka meslekten veya ilk mesleği bu olanların halkla ilişkiler konusunda görevini ifa ederken sıkıntılar yaşanıyor. Köprü vazifesi görmesi gerekirken, engel olan, zorluklar yaşatan bir birim veya kişi haline geliyor" (G21).

Halkla ilişkilerin geçmişte yaptığı çalışmaların kriz dönemlerinde etkisini tespit etmeye yönelik olarak olușturulan sorunun cevabında gazeteciler farklı görüşler belirtmiştir.Bazı gazetecilere göre kriz dönemlerinde gazetecilik refleksi ön plana çıkar ve kurumun geçmişteki başarısı bu haberlerin yapılmasına engel değildir. Bazı gazetecilere göre, krizden önce güvenilir bir kurum algısı önemlidir ancak kurum krize hazır olmalıdır. Kriz dönemlerinde önemli olan kurumun krize hazır olması ve krizi başarılı bir şekilde yönetmesi gazetecinin beklentisi olarak ortaya çıkmaktadır.

\section{Iletişsime geçilen öncelikli kişiler}

"Basın ve muhatap temsilcileri, kanaat önderleri olması gerekir" G1, G2, G3, G8, G9, G11, G12, G13, G16, G17, G19, G20, 21). "Bağlı bulunduğu kurumun en üst düzey yetkilisi olmalıdı" (G4, G5,G6, G7, G10, G15, G18). "Kurum çalışanları olmalıdır" (G14).

Görüşüne başvurulan gazetecilerin büyük çoğunluğu krizlerde öncelikli olarak iletişime geçilmesi gereken kişilerin kurum yetkilisi, basın, kanaat önderleri olması gerektiğini vurgulamaktadır. Bu bağlamda kurumların kriz dönemlerinde doğru bilgiyi kısa sürede ulaștırmak zorunda oldukları ve kurumun paydaşları olarak görülen kanaat önderleri, basın ve kurum çalışanlarının önemli olduğu görülmektedir.

\section{Kriz dönemlerinde ilk haber kaynağı}

"En üst düzey yönetici" (G1,G5, G7, G8, G9,G11, G12, G13, G15, G16, G17, G18, G19, G20). "İçeriden birileri ya da rakiplerden alınacak bilgiler önceliği alıyor" (G2). "Olayın kendisinin haber kaynağı olduğunu düşünüyorum" (G3). "Kurumların en üst düzey yetkilileri olmalıdır zira araya giren her bir yeni birey konuyu yanlış anlaşılmalara açık hale getirmektedir" (G4). "Kim daha güven veriyorsa odur" (G6)."Kriz dönemlerinde ilk haber kaynakları, kriz içindeki kurumlarda çalışan gizli kaynaklar olmalıdır" (G10)."Resmi kurumların yayınladığı metinler ve kurumun halkla ilişkileri" (G14). "Kriz döneminde en yetkili kurum kuruluşların halkla ilişkiler birimi olmalı. İlk elden kaynağa kolayca ulaşımı sağlayabilmeliler" (G21).

Kriz iletişim ekibinde, halkla ilişkiler yöneticisi ya da sorumlusu, finans müdürü, hukukçu, hissedar, pazarlama ve reklam sorumlusu, veri işletim ve büro hizmetlerinde çalıșan eleman bulunmalıdır (Okay ve Okay, 2001, s. 429). Kriz ekibinde yer alan halkla ilişkiler çalışanı ya da kriz sözcüsü medyaya bilgiyi ulaştıran kişi olabilmektedir. Gazetecilerin büyük çoğunluğu üst düzey yöneticinin ilk haber kaynağı olması gerektiğini ifade etmektedir. Ust düzey yönetici de basın sözcüsü olabilmektedir. Medyaya bilgiyi veren kişinin tek olması yanlış anlamaları da azaltmaktadır.

\section{Gazetecinin rolü}

“Gazeteci, ülkesinin menfaatlerini gözetmeli. Habercilik kurallarına riayet etmeli. Yıkıcı, kıșkırtıcı, ayrıștıııcı değil, yapıcı, tarafsız olmalı. Alıcıların doğru bilgiye ulaşmasında tek referans noktasıdır. Kriz anında doğru bilgiye ulaşıp, tarafların görüşlerini alarak habercilik yapmak güven ortamı açısından önemlidir " (G1, G2,G4, G5, G7, G8, G10, G11, G12, G13, G14,G15, G16, G17, G18, G19, G20). "Sorumlu bir gazetecilik yapılmalıdır. İnsan hakları, ülke ilişkileri, toplumun ahlaki ve kültürel değerleri daha fazla dikkate alınarak hareket edilmelidir" (G3, G6)."Kriz dönemlerinde gazetecilerle sağlıklı ve güçlü bir iletişim kurulmalıdır. Gazetecilere doğru ve hızlı bilgi aktarımı olmalıdır"(G9)."Halkı panikletmeden ve doğru bilgilendirerek oluşabilecek olumsuzlukları önlemeye yönelik bir habercilik olmalıdır" (G21).

Gazetecilerin büyük çoğunluğu kriz dönemlerinde nasıl habercilik yapmaları gerektiği ile ilgili bilgiye sahip oldukları ve sorumlu bir gazetecilik yapılması gerektiğinin bilincinde oldukları görülmektedir. Gazeteciler, halkı panikletmeden, doğru bilgilerle habercilik yapılmasını önermektedir.

\section{Krize yönelik kurumun ilk tepkisi}

"Soğukkanlııkla hareket edilmelidir. Kriz net bir şekilde analiz edilmeli. Daha sonra bu doğrultuda çözüm yolları aranmalı. Öncelikle krizi doğru olarak algılamalı, incelemeli ve analiz etmelidir. Krizin nasıl geliştiği, neler olabileceği ve neler yapılırsa krizden en az zararla kurtulanabileceği konusunda yol haritası yapılmalıdır. Sadece bir birim üzerinden değil, kurumdaki bütün birimlerden fikirler alınmalı ve bir beyin fırtınası mutlaka yapılmalı, kamuoyu menfaatleri ön planda tutulmalıdır" (G1, G5, G7, G10, G13, G15, G16, G18, G19, G20, G21)."Tezi çürütmeye çalışmaktan ziyade, hatayı gizlemek yerine doğru bilgiyi vermeli ve muhataplara ulaşabileceği tüm kanalları kullanmalıdır. Savaştan uzak durmalıdır, sakin, sağduyulu ve yönlendirici olmalı, kurum çalışanlarına doğru ve tam bilgi verilmeli"(G2, G3, G4, G8, G11, G12, G14, G17)."Kurum menfaatlerini korumaya yönelik tepkiler"(G6). "Anında basın yoluyla açıklama yapmalıdır" (G9).

Gazeteciler, kurumun krizi soğukkanlılıkla yönetmesini, kriz ekibinin sağduyulu davranmasını, ekip ruhuyla hareket etmesini, kurum çalışanlarına doğru ve tam bilginin verilmesini beklemektedir. Gazetecilerin büyük çoğunluğuna göre krizin başarılı yönetilebilmesi için krizin nedenleri analiz edilmeli ve kısa sürede krizi en az hasarla atlatmak için gereken önlem alınmalıdır.

\section{Kriz döneminde liderlik}

“Kriz döneminde lidere ihtiyaç vardır. Lider her zaman olumlu etkiler. Herkes ne yapacağını bilir, krizin derinleşmesini iyi bir lider önleyebilir. Karizmatik ve otoriter bir lider krizi daha sağlıklı yönetir" (G3, G4, G6, G8, G9, G10, G18)."Kriz dönemlerinde yöneticilerin deneyimli olmaları, o kuruma artı puan kazandırır. Kri- 
ze doğru yaklașan, analiz eden ve alt birimlerdeki insanları bu doğrultuda doğru yönlendirebilen liderler, her zaman kurumun en az zararla kurtulmasına yardımcı olmuşlardır"(G1, G2, G5, G7, G11, G21)."Her ortamda lider gereklidir. Dürüst ilkeli, iradeli ve bilgili kişiler krizde önemli rol oynayan kişilerdir" (G12). "Kriz durumunda insanlar paniğe kapılır, liderler insanları sakinleştirmelidir" (G13, G15, G16, G17, G20)."Krizde lider kurum çalışanlarını yönlendirilmelidir" (G14). "Elbette vardır. Zaten CEO'lar da bu nedenle vardır" (G19).

Kriz dönemlerinde kurumların lidere sahip olması krizin başarılı yönetilmesinde önemli rol oynamaktadır. Lider, kurum çalışanlarını doğru yönlendiren ve panik oluşmasını engelleyen bir aktör olarak işlev görmektedir. Gazeteciler, kriz dönemlerinde her kurumun lidere ihtiyacı olduğunu ve krizin en az hasarla atlatımasında rol oynadığını ifade etmektedir.

\section{Gazetecilerin krize etkisi}

"Milli şuurla hareket edebilen gazeteciler, ülkenin menfaatlerini gözeteceği için olumlu katkı yapabilmektedir. Krizin çözümüne olumlu yönde katkı sağlamalıdır"(G1 G3, G4, G9, G11, G13, G15)."Tamamen gerçekleri ön plana çıkarmak durumunda olumlu, çıkar elde etmek isterse olumsuz sonuçlar doğurabilir" (G2, G21)."Basın, krizi muhalif olduğu kurumlara karşı bir karalama kampanyasına dönüştürüyorsa, ya da yandaş olarak tabir edilen basın, yaşanan krizi daha düşük seviyedeymiş ya da hiç yaşanmıyormuş gibi gösteriyorsa bu olumsuz etki gösterir. Ama medya olaya objektif ve yapıcı bir şekilde yaklaşırsa, krizin en az zararla atlatılmasında büyük yararlar sağlayabilir"(G5, G14, G7, G10, G16, G17)."Yaptığı haberlerle krizlerin dedikodusunun yapılmasına sebebiyet vererek, kurumların imajını zedeleyebilir"(G6)."Doğru ya da yalan haber yaparak krizi azaltabilir ya da daha da derinleştirebilir" (G8, G12)."Etki olasıdır her zaman olumlu olacak değil olumsuz de etkileri olabilir" (G18)."Medya toplumu yönlendirmede en etkili araçtır. Dolayısıyla haberin belli şekilde manipüle edilmesi olumlu veya olumsuz yönde etki eder" (G19, G20).

Gazetecilerin krize etkisine bakıldığında genel olarak krizin haber yapılmasının kurumları olumsuz yönde etkilediği ancak medyanın objektif haber yaparak sorumluluğunu yerine getirmesi gerektiği belirtilmektedir.

\section{Krizin kuruma etkisi}

"Yaşanan olayın boyutuna ve etkisine göre değişiklik gösterir"(G2)."Kriz dönemleri kurumları olumsuz etkilemektedir. Kurumlar bazen geri dönüşü olmayan yaralar almaktadır. Bazen de yaraları sarması uzun zaman alıyor ve kurumları yıpratıyor»(G1, G4, G8, G11). "Kurum, kriz yönetimini doğru yapabiliyorsa, doğru adımlar atabiliyorsa yani krizi fırsata çevirebiliyorsa, diğer kurumlardan birkaç adım öne geçmesine ve krizden zarar yerine karla çıkabilmesine olanak sağlar. Ama kriz yönetimi iyi yapılmıyorsa krizden zararla çıkacaklardır" (G3, G5, G6, G7, G9, G20)."Kriz dönemleri kurumları yoğunlukla iki şekilde etkiler. Ticari kayıp ve itibar kaybı, tica- ri getiri ve saygınlık kazanımı" (G10). "Kriz ve sorunlardan ders çıkarmayı öğrenememiş toplumumuzda her zaman olumsuz etkiler devam etti, edecektir" (G12, G15, G16, G17, G19)."Kurumlara gelen bilgi bombardımanının içinde en doğru olanı bulma ve tarafsız kalabilmenin güçlüğü yașanmaktadır" (G13)."Kurumun halkla ilișkiler birimi doğru strateji ve taktikler belirlerse krizi fırsata çevirebilir" (G14). "Kurumların yıpranmasını önlemek amacı ile Halkla Ilişskiler Birimleri kapatıcı olarak değil daha net şeffaf bilgi veren yerler olarak değerlendirilmeli. Kiși odaklı yaklaşımların ve krizi yönetememe süreçlerinin kurumları daha çok yıprattığını düşünüyorum" (G18)."Kurumlar krizleri yönetmeleri neticesinde ivme kazanabilir. Doğru yönetemezse maddi manevi kayıplara ve imaj kaybı yaşayabilirler. Kriz yönetme durumuna göre kurumsallaşabilir veya piyasadan silinebilir. Toparlanma süreci ise uzun yıllar gerektirmektedir. Öngörüsü olan firmalar en az zararla hasarı atlatabilmektedirler" (G21).

Kriz, kurumu olumsuz yönde etkilemektedir. Ancak gazetecilere göre kriz doğru yönetilirse, en az hasarla atlatılır ve kurum krizi fırsata dönüştürebilir. Kriz doğru yönetilmezse, kurum maddi manevi kayıplara uğrayabilir ve imaj kaybı yaşayabilir. Gazeteciler aynı zamanda krizin kurumu yıprattığını ve büyük yaralar aldığını vurgulamaktadır.

\section{Değerlendirme}

Kriz dönemleri halkla ilişkiler çalışanları açısından zor ve kurum için en az zararla atlatılması gereken dönemlerdir. Kriz dönemleri gazeteciler açısından da doğru bilgiye en kısa sürede ulașma telașı nedeniyle stres yaratan durumlardır. Bu zor dönemi gazetecilerin ve halkla ilişkiler çalışanlarının başarı ile atlatabilmesi için karşııklı güven, anlayış ve birbirinin mesleğine saygı önem arz etmektedir. Bu bağlamda çalışma, kriz dönemlerinde gazetecilerin halkla ilişkiler çalışanlarından beklentilerini ortaya koymaya yöneliktir. Kriz dönemlerinde gazeteciler, halkla ilişkiler çalışanlarından öncelikli olarak doğru bilgiyi en kısa sürede ulaştırmalarını talep etmektedir. Doğru bilginin kısa sürede ulaştırıması kurumun krizi en az hasarla atlatması için gerekir görüşüne hâkim olan gazeteciler, pratikte bunun mümkün olmadığını dile getirmektedir. Gazeteciler, halkla ilişkiler çalışanlarının bir amir ya da müdüre bağlı olmasının alınan bilgiyi tartışmalı hale getirdiğini, halkla ilişkiler çalışanlarının doğru bilgiyi vermede engel yaşadıklarını, kurumun zarar görmemesi için bilgi vermekten kaçındıklarını bu nedenlerle halkla ilişkiler çalışanlarının iyi bir haber kaynağı olamadıklarını belirtmişlerdir. Gazetecilere göre halkla ilişkiler çalışanları kriz döneminde yeterli bilgiyi zamanında medyaya ulaştıramamaktadır. Bu dönemde yanlış ve taraflı bilgilerin verilmesi, doğru bilgiye ulaşımı engellemektedir. Bilgilerin teyit edilmesi konusunda geç kalınması, olayı gizlemek isterken bilgi kirliliğinin oluşması gibi olumsuzluklar yapılan haberlere yansımaktadır ve dolayısıyla kamuoyu yanıltılabilmektedir.

Gazetecilere göre, kriz döneminde halkla ilişkilerin rolü, herkese eşit şekilde bilgi vermek, kamuoyunun krizden en az seviyede etkilenmesini sağlamak, doğru bilgiye en kısa sürede gazetecilerin ulașmasına yardımcı olmak, yöneticiler ile gazeteciler arasında köprü vazifesi görmek, olayları çarpıtmadan, gizlemeden gazetecilere 
ulaștırmak ve gazetecileri doğru yönlendirmek olarak belirtilmektedir. Halkla ilișkiler biriminin krize ilk tepkisi gazetecilere göre soğukkanlı davranmaktır. Ayrıca krizin nedenleri analiz edilmeli, doğru bilgi verilmeli, sağduyulu hareket edilmeli ve kurum çaış̧anlarına doğru ve tam bilgi verilmeli, zamanında basın aracılığıyla açıklama yapıımalı şeklinde açıklanmaktadır. Kriz dönemlerinde halkla ilişkiler birimlerinin iletişime geçmesi gereken kişiler olarak medya, kanaat önderleri, kurumun üst düzey yöneticileri, kurum çalışanları olarak sıralanmaktadır. Bu kişilerin kriz ekibi içerisinde yer alan kișiler olmaları ve bu kişilere kriz eğitimi verilmesi açısından değerlendirildiğinde gazeteciler, her ne kadar kriz alanında eğitim almamış olsalar da gazetecilerin halkla ilişkiler çalışanının kriz döneminde ne kadar önemli olduğunun farkında olduğunu göstermektedir.

Kriz dönemlerinde liderlerin etkili olduğunu belirten gazeteciler, karizmatik, otoriter bir liderin krizi daha sağlıklı yöneteceği, krizin derinleşmesini önleyeceği, kurumun krizden en az zararla kurtulmasına yardımcı olacağı, panikleyen insanları sakinleştireceği görüşüne hâkimdir.Kriz dönemlerinde liderler önemli bir sorumluluk üstlenerek krizin hasarlarını en alt seviyeye indiren kişiler olarak değerlendirilmektedir. Gazeteciler kriz dönemlerinde kurumun en üst yöneticisinin/liderin konu ile ilgili açıklama yapmasını talep etmektedir. Bu nedenle zor dönemlerde ilk haber kaynağı olarak kurumun en üst düzey yöneticisi görülmektedir. Gazetecilerin yaptıkları haberlerle krize etki ettiği, genellikle olumlu etki yarattığı ancak kurumun yapısına göre olumsuz da olabileceği, medyanın toplumu yönlendirmede etkili araç olduğu, krizde kurumun imajının zedelendiği ancak krizin fırsata da dönüştürülebileceği ifade edilmiştir. Gazeteciler kriz dönemlerinde kamu menfaati söz konusu olduğunda medyanın işbirliği yapmasından yana bir kanaat bildirmișlerdir. Bu durum gazetecilerin kamu menfaatleri söz konusu olduğunda birlikte hareket etme bilinci oluşturduklarını göstermektedir. Gazetecilerin kriz ile ilgili eğitim alıp almadıkları sorusuna \% 57 (n=12)'i hayır, \% 43 $(n=9)^{\prime} i$ evet yanıtını vermiştir. Gazetecilerin kriz haberlerini daha bilinçli yapmaları için kriz ile ilgili eğitim almalarının faydalı olacağı düşünülmektedir.

\section{Sonuç}

Halkla ilişkiler çalışanları ile gazeteciler madalyonun iki yüzü olarak değerlendirilebilir. Birbirlerinin çalışma şekillerini önemli oranda etkileyen bu ikilinin ilişkisi hiç kuşkusuz çok önemlidir. Özellikle kriz dönemlerinde kamuoyunu bilgilendirme açısından gazetecilerin toplumda panik oluşturmadan haberlerini sunmaları bir başka deyişle meslek etik kurallarına uyarak görevlerini yapmaları, halkla ilişkiler çalışanlarının da aynı şekilde dürüst, şeffaf ve doğruluk üzerine çalışmalarına yön vermeleri ilişkinin sürekliliği açısından da gereklidir.

Sonuç olarak halkla ilişkiler çalışanları kriz döneminde hızı hareket ederek öncelikli olarak medyayı ve çalışanlarını bilgilendirmeli, doğru strateji ve taktiklerle krizi fırsata dönüştürmek için çabalamalı, doğru bilgiyi zamanında medyaya değil kamuoyuna ulaştırdığını düşünerek hareket etmelidir. Aslında her iki mesleğin mesleki etik kodlarına dikkat edilerek yapılması durumunda kamuoyunun doğru bilgilendirileceği ortaya çıkmaktadır. Gazetecinin kaynağı güvenilir olmayan ve doğruluğu kanıtlanmayan bilgileri hızlı haber yapma telașıla göz ardı etmemesi mesleki ahlak ilkelerinde belirtilmektedir. Aynı durum halkla ilişkiler çalışanları için de geçerlidir. Halkla ilişkiler çalışanları meslek ilkelerine bağlı kalarak şeffaflık ilkesini özümseyerek gazetecilere görevlerini yaparken yardımcı olmaları ve gazetecilere doğru bilgiyi kısa sürede ulaştırma çabası içerisinde olmaları gerekmektedir Çünkü kurumların kriz ve normal dönemlerinde de medyaya ihtiyaçları bulunmaktadır. Bu iletişimin dürüstlük ve șeffaflık üzerine kurulması durumunda ilişkinin uzun süre devam edeceği öngörülmektedir.

Kriz dönemlerinde gazetecilerin halkla ilişkiler çalışanlarına bakış açısını ortaya koymaya yönelik olan bu çalıșma gazetecilerin yanıtları ve olușturulan sorular ile sınırlıık oluşturmaktadır. Bundan sonraki süreçte kurumun reklam veren özelliğinin gazetecinin krize yaklaşımını etkileyip etkilemeyeceği konusunda yapılacak bir araştırma alana katkı sağlayacağı için önerilebilir. Ayrıca haber kaynakları arasında yer alan halkla ilişkiler çalışanlarının süreci nasıl etkilediği ve gazeteciler üzerinde nasıl bir etkiye sahip oldukları bir başka araştırmanın konusu olma potansiyeline sahiptir.

\section{Kaynakça}

Akdağ, M. (2005). Halkla İlişkiler ve Kriz Yönetimi. Selçuk Üniversitesi Sosyal Bilimler Enstitüsü Dergisi, 14, 1-20.

Akım, F. (2005). Kriz Yönetimi ve Halkla İlişkiler. İstanbul Üniversitesi İletişim Fakültesi Dergisi, 22, 171-176.

Arpan, M. L. ve Pompper, D. (2003). Stormy weather: Testing "Stealing Thunder» as a Crisis Communication Strategy to Improve Communication Flow Between Organizations and Journalists, Public Relations Review, 29, 291-308.

Aslan, K. (2002). Haberin Yol Haritası. Ankara: Anahtar Kitaplar Yayınevi.

Aslan, K. (2008). Değişen Teknolojiler ve Habercilikte İstihbarat. İstanbul: Anahtar. Callison, C. ve Seltzer, T. (2010). Influence of Responsiveness, Accessibility and Professionalism on Journalists Perceptions of Southwest Airlines Public Relations, Public Relations Review, 36, 141-146.

Can, H. (2002). Organizasyon ve Yönetim. Ankara: Siyasal.

Cameron, G.T., Sallot, L. M. ve Curtin, P. A. (1997). Public Relations and the Production of News: A Critical Review and A Theoretical Framework. B.R. Burleson (ed.), Communication Yearbook 20, Routledge, Routledge, New York, 111-155.

Charron, J. (1989). Relations Between Journalists and Public Relations Practitioners: Cooperation Conflict and Negotiation. Canadian Journal of Communications, 14(2), 41-54.

Cravens, K. S. ve Oliver, G. E. (2006). Employees: The Key Link to Corporate Reputation Management. Business Horizons, 49(4), 293-302. 
Coombs, W. T., \& Holladay, S. J. (2009). Further Explorations of Post-crisis Communication: Effects of Media and Response Strategies on Perceptions and Intentions. Public Relations Review, 35(1), 1-6.

Çaplı, B. ve Taş, O.(2009). Televizyon Haberciliğinde Etik Sorunlar. B. Çaplı ve H. Tuncel, (Ed.), Kriz Haberciliği içinde (237-250). Ankara: Fersa.

Çamdereli, M. (2000). Ana Çizgileriyle Halkla Illişkiler. Konya: Çizgi.

Davies, N. (2009). Flat Earth News. London, UK: Random House.

Demir, F. (2015). Stratejik İletişim ve Algı Yönetimi Bağlamında Kriz Illetişim Yönetimi. International Journal of Human Sciences, 12(1), 343-362.

Demirtaş, H. (2000). Kriz Yönetimi. Kuram ve Uygulamada Eğitim ve Yönetim Dergisi, 23, 353-373.

Erdoğan, i. (2006). Türkiye'de Ulusal ve Yerel Gazetelerin Habercilik Anlayışları: Deprem Haberlerinin Karşılaştırmalı Analizi. Selçuk IIletişim Dergisi, 4(3), 51-64.

Fırat Güngör, D. (2011). Kriz Dönemlerinde Televizyon Yayıncılığı. RTÜK uzmanlık tezi, Ankara.

Grunig, J.E. ve Hunt, T.T. (1984). Managing the Public Relations. New York: CBS College.

Grunig, J. E., Grunig, L. A., \& Dozier, D. M. (2006). The Excellence Theory. In C. H. Botan, \& V. Hazleton (Eds.), Public Relations Theory II (pp. 21-62). Mahwah $\mathrm{NJ}$ : Lawrence Erlbaum Associates.

Göztaş, A. (1997). Kriz Yönetimi ve Halkla Illişkiler. İzmir: Ege.

Gürüz, D. (1993). Halkla Illişkiler Teknikleri. İzmir: Ege Üniversitesi Iletişim Fakültesi Yayınları.

Holtz, S. (1999). Public Relations on the NET, American Management Association, USA.

Hürmeriç, P.(2016). Halkla Illişkiler ve Etik: Süregiden Tartışma. Illetişimin Gücü, Kurumsaldan Küresele Halkla iliş̧kiler (ed: F.Balta Peltekoğlu).Istanbul: Beta Basım Yayım Dağıtım.

Joosub, T. S. (2006). Risk Management Strategies to Maintain Corporate Reputation, Master Tezi, University of South Africa Business Management.

Ihlen, Q. ve Pallas, J. (2014).Meditization of Corporations. Knut Lund by (ed.), Handbook on Mediatization of Communication. Berlin: De Gruyter Mouton.

İnceoğlu, Y. (2000). Uluslararası Medya. İstanbul: Beta Yayınları.

Johnston, J. (2013). Media Relations: Issues and Strategies. Sydney: Allen\&Unwin.

Kadıbeşegil, S. (2001). Halkla İlişkilere Nereden Başlamalı?. İstanbul: MediaCat.
Kazancı, M. (1996). Halkla İlișkiler. Ankara: Ankara Üniversitesi Illetișim Fakültesi Yayınları: 6.

Kazancı, M. (2002). Kamuda ve Özel Kesimde Halkla Illişkiler. Ankara: Turhan Kitabevi. Kent, M. L., \& Taylor, M. (1998). Building Dialogic Relationships Through the WorId Wide Web. Public Relations Review, 24, 321-334

Koç Akgül, S. (2017). Olağanüstü Durumlar, İletişim ve Habercilik Yaklaşımları, Olağanüstü Dönemlerde Yayıncılık. TRT Akademi, 2(3), 6-47.

Langett, J. (2013). Meeting the Media: Toward an Interpersonal Relationship Theory Between the Public Relations Practitioner and the Journalist. PRism 10(1):http://www.prismjournal.org/homepage.html.

Lewis, J., Williams, A., Franklin, B., Thomas, J., \& Mosdell, N. (2008). The Quality and Independence of British Journalism: Tracking the Changes of 20 Years. Research Report Wales: Cardiff School of Journalism, Media and Cultural Studies, Cardiff University.

Macnamara, J. (2014). Journalism-PR Relations Revisited: The Good News, The Bad News and Insights Into Tomorrow's News. Public Relations Review, 40, 739-750.

Patricia, A. C. (1999). Reevaluating Public Relations Information Subsidies: Market-Driven Journalism and Agenda-Building Theory and Ractice. Journal of Public Relations Research, 11(1), 53-91.

Peker, Ö. ve Aytürk, N.(2000). Etkili Yönetim Becerileri Öğrenilebilir ve Geliştirilebilir. Ankara: Yargı.

Preselj, V., Gašpar, M. S., \& Petrovi, M. 2017. Crisis Communication on Social Media, Living in, 225

Pira, A. ve Sohodol, Ç. (2004). Kriz Yönetimi. İstanbul: Iletişim.

Okay, A. ve Okay, A. (2014). Halkla Illişkiler, Kavram, Strateji ve Uygulamaları. İstanbul: Der.

Oktay, M. (1996). Halkla Ilişkiler Mesleğinin İletişim Yöntem ve Araçları. İstanbul: Der.

Öksüz, B. ve Korap Özel, E. (2015). Gazeteciler ve Halkla Illişkiler Uygulamacılar Arasındaki Gergin İlişkinin Kodları: Gazeteciler ve Halkla Illişkiler Uygulamacıları Üzerine Bir Araştırma. Selçuk İletişim Dergisi, 9(1), 22-54.

Pincus, D. Rimmer, T., Rayfield, R. E. \& Cropp, F. (1993). Newspaper Editors' Perceptions of Public Relations: How Business, News, and Sports Editors Differ Journal of Public Relations Research, 5(1), 27-45.

RTÜK(2008). Terör ve Medya. Bilgilendirme toplantısı, İstanbul.

Sabuncuoğlu, Z. (2004). İşletmelerde Halkla İlişkiler. İstanbul: Alfa Akademi.

Sevencan, F. ve Çilingiroğlu, N. (2007). Sağlık Alanındaki Araştırmalarda Kullanılan Niteliksel Veri Toplama Yöntemleri. Toplum Hekimliği Bülteni, 26(1), 1-6. 
Sissons, H. (2012). Journalism and Public Relations: A Tale of two Discourses. Discourse \& Communication, 6(3), 273-294.

Tarhan, A. (2013). Halkla Illişkilerde Medyayla Ilişsiler: Medya Çalışanlarının Görüşleri Üzerine Bir Saha Araştırması. NWSA-Humanities, 8(2), 226-251.

Tekin, H. H. (2006). Nitel Araştırma Yönteminin Bir Veri Toplama Tekniği Olarak Derinlemesine Görüşme. İstanbul Üniversitesi Sosyoloji Dergisi, 3(13), 101-116.

Tılıç, L. D. (1998). Utanıyorum Ama Gazeteciyim-Türkiye ve Yunanistan'da Gazetecilik. İstanbul: Illetişim.

Uzun, R. (2007). İletişim Etiği Sorunlar ve Sorumluluklar. Ankara: Gazi Üniversitesi Illetişim Fakültesi Basımevi.

Uzunoğlu, E. ve Öksüz, B. (2008). Kurumsal İtibar Riski Yönetimi: Halkla Illişkiler Rolü. Selçuk İletişim Dergisi, 5(3), 111-123.

Ülger, B. (2003). İşletmelerde İletişim ve Halkla İlişkiler "The Big Business." İstanbul: Der.

Van der Meer, Toni G.L.A.,Verhoeven, P., Beentjes, J.W.J. \& Vliegenthart, R. (2017). Disrupting Gatekeeping Practices: Journalists Source Selection in Times of Crisis. Journalism, 18(9), 1107-1124.

Vural Keskin, i. (2006). Kriz Haberciliği ve Haberci Kişilik Olarak Anchor-Sinagog, HSBC Bankası ve Ingiliz Konsolosluğuna Yönelik Gerçekleştirilen Terör Eylemlerine Illişkin Bir Değerlendirme, Terörün Görüntüleri Görüntülerin Terörü, ed: Orhan Gökçe-Uğur Demiray, Çizgi Kitabevi.

Weiner, D. (2006). Crisis Communications: Managing Corporate Reputationin the Court of Public Opinion. March/April, Ivey Business Journal.

White, J. ve Hobsbawm, J. (2007). Public Relations and Journalism. Journalism Practice, 1(2), 283-292.

Yayınoğlu Eraslan, P. (2013). Gazetecilik ve Halkla Illişkiler Mesleği Mücadele mi, İşbirliği mi?. İstanbul: Türkmenevi.

Yüksel, E. (2006). Gerçek Yaşam, Medyadaki Gerçek ve Terör Haberciliği. Terörün Görüntüleri, Görüntülerin Terörü, Konya: Çizgi Kitabevi.

Yüksel, E. (2010). Medya ve Habercilik. Konya: Çizgi Kitabevi. 